Portland State University

PDXScholar

\title{
An Expanded Perceptual Laboratory: Public Art and the Cinematic Techniques of Superimposition, Montage and Apparatus/Dispositif
}

Dave Colangelo

Portland State University, dcolang2@pdx.edu

Follow this and additional works at: https://pdxscholar.library.pdx.edu/ta_fac

Part of the Film and Media Studies Commons, Interactive Arts Commons, and the Interdisciplinary Arts and Media Commons Let us know how access to this document benefits you.

\section{Citation Details}

Colangelo, Dave, "An Expanded Perceptual Laboratory: Public Art and the Cinematic Techniques of Superimposition, Montage and Apparatus/Dispositif" (2015). School of Film Faculty Publications and Presentations. 15.

https://pdxscholar.library.pdx.edu/ta_fac/15

This Post-Print is brought to you for free and open access. It has been accepted for inclusion in School of Film Faculty Publications and Presentations by an authorized administrator of PDXScholar. Please contact us if we can make this document more accessible: pdxscholar@pdx.edu. 


\section{An Expanded Perceptual Laboratory: Public Art and the Cinematic Techniques of Superimposition, Montage and Apparatus/Dispositif}

\section{DAVE COLANGELO \\ Ryerson University}

dave.colangelo@gmail.com

3515 Ponytrail Dr.

Mississauga, Ontario

L4X 1V9

Canada

\section{ABSTRACT}

The use of the moving image in public space extends the techniques of cinemanamely superimposition, montage and apparatus/dispositif-threatening either to dehistoricize and distract or to provide new narrative and associative possibilities via public art. These techniques also serve as helpful tools for analysis drawn from cinema studies that can be applied to examples of the moving image in public space. Historical examples include the multi-screen experiments of Charles and Ray Eames; and contemporary public projections such as Krzysztof Wodiczko's Abraham Lincoln: War Veteran Projection, Robert Lepage's The Image Mill, my own project entitled Workers That Live in the Mirror, and Daily tous les jours' McLarena at Montreal's Quartier des Spectacles. These works illustrate the ways that public projections extend the effect of superimposition through the rehistoricization of space, expand the diegetic boundaries of the moving image through spatial montage, and enact new possibilities for the cinematic apparatus and dispositif through scale and interaction for the purposes of challenging historical narratives and scripts of urban behavior. The large-scale 
moving image in public art extends the perceptual laboratory of cinema to public space preparing us for more mutable, oneiric and cinematic encounters in and through public art.

\section{BIOGRAPHICAL NOTE}

Dave Colangelo is a media artist and adjunct professor in the History of New Media Art program at OCAD University (formerly Ontario College of Art and Design) in Toronto. He is also a research consultant at Streaming Museum, a curatorial network for public spaces and cultural centers based in New York City. He holds an M.A. in Cultural Studies from Goldsmiths, University of London, and a Ph.D. in Communication and Culture from Ryerson and York Universities. His work investigates the relationship between the moving image, digital culture and public art. Colangelo's writing has appeared in the Leonardo Electronic Almanac and The Journal of Curatorial Studies. His work (with collaborator Patricio Davila) has appeared at the International Symposium for Electronic Art in Istanbul (2011) and Sydney (2013), the Biennale of Architecture and Urbanism in Shenzhen/Hong Kong (2013-14), and the 2014 Media Architecture Biennale in Århus, Denmark.

\section{KEYWORDS}

Charles and Ray Eames, Daily tous les jours, dispositif, Krzysztof Wodiczko, montage, Quartier des Spectacles, Robert Lepage, superimposition 


\section{AN EXPANDED PERCEPTUAL LABORATORY: PUBLIC ART AND THE CINEMATIC TECHNIQUES OF SUPERIMPOSITION, MONTAGE AND APPARATUS/DISPOSITIF}

\section{DAVE COLANGELO}

\section{INTRODUCTION}

Cinema can be defined as a collection of techniques-a set of resources and methods of construction, technical limitations, and possibilities. For example, superimposition, perhaps the very engine of cinema, creates the succession of images that produces the effect we perceive as motion and thus generates both attention and distraction in the viewer. It is one of the primary ways that cinema creates affect. A car appears to race down a highway, or we see, as in Chris Marker's La Jetée (1962), an eye blinking, just for a moment, and it sets our hearts racing. Montage, the juxtaposition of diverse images-the grammar of cinema so to speak-is also one of cinema's primary techniques. It presents us with a means of suggesting associations and relations between things. It connects the shocked expressions of onlookers in Sergei Eisenstein's Battleship Potemkin (1925) with the brutality of the advancing troops on the Odessa steps, again riveting us to the diegesis through the narrative and associative power it generates. Finally apparatus and dispositif contribute to the effect of cinema in the pairing of technique, architecture and ideology through the act of spectatorship. For example, the darkened spaces of cinema facilitate a transferral (or deferral) of identity and subjectivity for the viewer. The cinema is a mechanism of ideological transmission that can be employed to deliver to its 
audience various encoded messages in content and form, be it the male gaze, ${ }^{1}$ or another discourse (i.e. capitalism).

Taken together—superimposition, montage and apparatus/dispositifconstitute three ways that cinema can be viewed as a "perceptual laboratory": as media theorist Scott McQuire notes, forming meaning and shaping experience by centering and recentering the audience and generating affect. ${ }^{2}$ McQuire's concept of the relationship between media and perceptual training and experimentation follows from Walter Benjamin's observation that a primary effect of cinema was to make manageable one's experience of the rapidly modernizing city of the early twentieth century by way of first shocking and then habituating the senses through the media equivalent of the view from a speeding train or from the window of a café looking out onto a busy street. ${ }^{3}$ The concept of the perceptual laboratory can be extended to public spaces that have, over time, taken on some of the same functional characteristics of cinema. ${ }^{4}$ Thus public space can be seen as an expanded perceptual laboratory where cinema and the city are no longer co-constitutive but imbricative and recursive in their effects of rupture and recuperation. Public projections and large-scale moving image displays, particularly in public art more so than the more prevalent examples of their commercial use, illustrate this phenomenon best as they deliberately experiment with these new assemblages of light, space and publics: they pose questions about how we come to know ourselves and one another in a world increasingly defined by the moving image, tangible interfaces and responsive, participatory, data rich environments. 
In this essay I argue that techniques and tools drawn from cinema studies (superimposition, montage and apparatus/dispositif) can be applied to examples of the moving image in public space in order to analyze the ways these techniques evolve in public settings and how they can create new perceptual and creative possibilities for the cinema and the city through public art. In turn, while providing historical perspectives on the transformation of cinema with and in public space (drawing upon Jonathan Crary's research of Sigmund Freud's observations of projected images in a public square in Rome in the early twentieth century, the multi-screen experiments of Charles and Ray Eames in the middle of the century, and the expanded cinema of the 1970s), I will argue that public spatialized art forms such as urban screens, media facades and projections generate cinematic superimpositions in order to dehistoricize spaces even as they open the possibilities for their rehistoricization. Works such as Krzysztof Wodiczko's Abraham Lincoln: War Veteran Projection (2012, New York City), for example, illustrate how space can be concealed (to a degree) just as it is drawn anew. I will also argue that, beyond cinematic montage we must now add a variant we might call "spatial montage," not in the digital sense of the composite screen-based image comprised of many layers that Lev Manovich describes, ${ }^{5}$ but in the sense that we must consider the immediate surface and surroundings of the screen as elements that can be juxtaposed with the moving image and counted within its diegesis. With public projections and urban screens the line between the diegetic and the extra-diegetic are inevitably blurred and thus must factor into the consideration of artists working in this medium. Robert 
Lepage's outdoor projection Le Moulin à images/The Image Mill (2008-13, Quebec City) and one of my own public projection works (with collaborator Patricio Davila), Worker's That Live in The Mirror (2013, Toronto), serve as examples of active engagement with the environment as relational frame. Finally I will argue that we must augment our understanding of the standard technicities of cinematic spectatorship to include a sense of the viewer as a peripatetic vector of potentiality within an apparatus/dispositif that can be algorithmic, responsive, urban and spatially variable. In digital public projections, for example, the cityscape and the infoscape become the apparatus, and thus shift the dispositif of the city and cinema into something that resembles a mixture between urban geography, UX/UI (user experience and user interaction) and traditional elements of cinema. Interactive public installations such as McLarena (2014, Montreal) by Daily tous les jours at the Quartier des Spectacles in Montreal exemplify the ways that large-scale public, moving image based works are created and installed in conditions that seek equivalents of the historical apparatus of cinematic spectatorship (such as the dark of night, sloped/stadium seating areas or vistas and sound or interaction spaces) while also incorporating new digital tools and their affordances in order to recenter and habituate a public art audience. In building upon the techniques of cinema, new moving image public artworks extend the perceptual laboratory of cinema to public space, preparing us for a fast approaching future of computer generated, mutable and oneiric spaces with all their associated perceptual dangers and delights. 


\section{Superimposition}

As Gene Youngblood notes: "The pure art of cinema exists almost exclusively in the use of superimposition." With cinema we see an image—rather we see 24 images a second-and we suture each to the next as the indexed stills on their filmic, magnetic or digital substrates unfurl. Cinema works due to the radical contingency of the image it presents to us; the instability of the image is its very nature and the engine that drives its subsequent affect. Contingency via superimposition is central to the affective register, ${ }^{7}$ and is the key to capturing our attention and making meaning out of what we see on screen.

It is in early practices of film taken outdoors, as well as in the rapidly electrifying city of the twentieth century, that the succession of moving images began to merge with space. Hubs of electrification such as New York City's Times Square became sites of performance, spectacle, pleasure and disorientation—battlegrounds for directing attention that merged cinematic and architectural experience to produce novel effects. ${ }^{8}$ Electrification and projection transformed the surfaces of the city into mutable, oneiric, "formless fields of attraction." ${ }^{9}$ It also transformed these spaces, akin to the cinema, into perceptual laboratories where attention, emotion, orientation and semiotic association were experimented with and tested. One of the outcomes of such experimentations, of the effects of the "formless fields of attraction" created by the moving image in public space, is the "dehistoricization" of space where the moving image serves to distract viewers from existing historical reference points. ${ }^{10}$ Jonathan Crary's examination of a letter Sigmund Freud wrote to his family in 1907 (describing his 
visit to Rome's Piazza Colonna) provides a telling example of this. In the centuries-old square Freud witnesses "lantern slides," "short cinematographic performances" and advertisements projected on a screen at the end of the piazza. ${ }^{11}$ In the letter, written in his room later that evening, Freud is neither able to recall if the Piazza contained a fountain nor does he mention the significance of the monumental column for which the space is named. These may seem like trivial details but Crary suggests that there is more to Freud's distracted confusion. That Freud is, in his own words, "spellbound" in front of the cinematograph and unable to recall additional information about the space shows just how effective this projection was in capturing Freud's attention. It also suggests that the moving image in public space may carry a greater syncretic and thus ideological significance than the cinema itself: not only did it capture Freud's attention, delivering him to the projected images and their meanings, it distracted him from his surroundings leaving the door open for the recontextualization of this space. The flow of images, especially in their repetition (Freud watches the same clips multiple times), can instil new knowledge and feeling about space through an accelerated ritual that redirects the coding of that space. In this case the surroundings and their cultural significances appear inert to Freud: they are forgettable and thus forgotten. As Crary notes:

The dematerialization of architectural surfaces into projection screens signals the reversibility of what had been established figure/ground relations within an urban fabric, and the screen on these Roman rooftops effectively displaces the built city to the oblivion of a cognitive periphery. ${ }^{12}$ 
Thus, for Crary, public projection is a harbinger of "a dehistoricized perpetual present" ${ }^{13}$ the moving image, applied to public space, can turn that space into a laboratory where perception and awareness can be decisively shaped. Freud remembers the images but forgets what is behind or around them.

Later, amidst the material and electronic flux of the modern city adorned with more and more formless fields of attraction, the walls of the city and the stories they contained receded. In visiting Times Square, Marshall Berman warned that "you have to tie yourself to some sort of inner mast in order not to be overwhelmed." ${ }^{\text {14 }}$ The maelstrom of impressions of/in electrified urban space brought with it a heavy dose of distraction-from others, from oneself and from the urban environment in general. At the turn of the twentieth century sociologist George Simmel theorized that the bombardment of the senses by way of the accelerations associated with rapid urbanization contributed to a generalized "blasé" attitude that had to be adopted by the urban dweller so they might survive this maelstrom. ${ }^{15}$

But is the powerful effect of moving image media in space only capable of dehistoricizing the past and present by obliterating the space around it? Does it necessarily lead to the eventual numbing of spectators' overtaxed senses? To which ends might this potent technique be directed in public space, and how has public art figured in such experiments? Finally given that contemporary moving image works in public space can achieve contingency along various axes through indeterminate viewing conditions, ${ }^{16}$ and the disruptive potential of digital forms (including the ability to interact with and recombine images with greater freedom 
and fluidity), ${ }^{17}$ what other frontiers for the shaping of affect and attention exist in the display of interactive moving images in public?

The result of the urban layering of cinematic superimpositions appears consistent with the general effect of cinema observed by early theorists of cinematic reception, which remains somewhat more open and optimistic in contrast to Simmel's and Crary's views. In Theory of Film (1960) Sigfried Kracauer argues that film creates an effect that captivates an audience and acts as a unique and powerful physiological stimulus. It does so in its recording of "reality," its revealing of certain aspects of reality that are otherwise hidden or located in another space and time, and its rendering of this reality in motion (through superimposition of frame after frame). ${ }^{18}$ Kracauer likens film to an object of prey, tapping into our animalistic tendencies to notice and fixate on moving objects. The subsequent increased demand on the spectator's sensorium results in a distraction, but also has the potential to generate innate curiosity and an openness to new sense impressions.

While advertisements that use the moving image in public space on billboards and projections often tap into the affective capabilities of cinema to make consumers forget everything except for the need to consume, public art that engages the moving image and public space demonstrates the ways that dehistoricization and distraction are neither necessarily detrimental to historical consciousness in these spaces nor the only outcome of the layering of flickering images and (relatively) flat architecture. In fact a number of works show how public projection and urban screens can rehistoricize a space through the 
dehistoricization made possible by the moving image, and thereby give us good reason to pay closer attention. From Jenny Holzer's work, namely Truisms (197779) which included the display of the words "MONEY CREATES TASTE" on New York City's Spectacolor board in Times Square in the late 1970s, to the more recent participatory digital graffiti of Brooklyn's Graffiti Research Lab that allows people to "tag" a public façade through a combination of lasers, sensors and digital projection, the illuminated image in public has proven to be a powerful tool for collectivity, dissent and dissensus and for contesting the specific politics of disengagement and fragmentation inherent in public space. Krzysztof Wodiczko's Tijuana Projection (2001), a landmark example of public practice and the moving image, involved the projection of live video of the faces of abused and exploited women in the local maquiladora industries on the façade of Tijuana's largest art gallery. Wodiczko's work used public projection to draw attention to historically and geographically relevant traumas and confronted viewers with this information to spark important conversations and even actions regarding social justice. According to Wodiczko the public aspect of this work helps to make social justice what he believes it should be: a collective and compassionate endeavor where "fearless speaking" meets "fearless listening." As the artist notes, "public truthtelling (testimony) and public truth-seeking (witnessing) are interdependent." ${ }^{19}$ To stop, watch and participate in such events implies complicity of the audience and the city (to a degree) with the disruptive image and its alternative message. And so while Wodiczko's work dehistoricized the modernist symbol of its architectural substrate, it also rehistoricized and politicized it through the 
superimposition of the moving image, transforming the site into an experiment in reimagining public space through the contingency and relationality afforded by the moving image (Figure 1).

A more recent example of a rehistoricization of space by way of the moving image, also by Wodiczko, is Abraham Lincoln: War Veteran Projection (2012). The month-long, nightly installation involved a video of American soldiers speaking about their experiences of tours of duty in Afghanistan projected onto the statue of Abraham Lincoln in New York City. It appeared as if the statue itself were coming alive with these ghostly images. With this work Wodiczko reinvigorated a statue that was erected shortly after the Civil War allowing it once again to become a site of dialogue about war, perhaps one more critical than was originally intended. While dehistoricizing this space-masking its surface and drawing attention away from the surroundings and existing meanings and didactic markers-Wodiczko employed a counter-monumental approach that used the moving image to temporarily recode the monument, appropriating and displacing it through its own symbolic inertia. Wodiczko unlocked and redirected the associative potential of the site and focused an urban audience that would likely otherwise pass it by, especially in the evening. Wodiczko also demonstrated the recoding of space through the alternative accelerated ritual of observing moving images: unlike the sculpture behind it, the moving images possessed an inherent contingency that called for attention for a prescribed period of time (particularly when coupled with audio), often at the expense of the sensory environment around the statue (Figure 2). 
What Wodiczko's work shows us is that the overall effect of the moving image in public space, the outcome of its experimental hypothesis, need not be one of disorientation and distraction. It can be one of rehistoricization-a critical redefinition of space that changes what can be said, by whom, and at which scale and level of authority. While the immediate succession of images that imply motion captivates and confounds us, stopping us in our tracks, with a large outdoor projection the image that sticks to a place in space-and a space in memory-affords us a new way to express and experience plurality and memory. Thus the image resists the foreclosure of meaning, particularly when applied to existing monuments and structures. The moving image in public space presents us with a new possibility for the "deposit of a memory trace" onto our surroundings to make them more legible, memorable and meaningful. ${ }^{20}$

With the addition of the moving image and its superimpositions, the city becomes, like the cinema before it, a "perceptual laboratory" where experiments and contests of identity, attention and aesthetics are conducted. ${ }^{21}$ Akin to the cinema, the city becomes a place where our systems can be shocked and reactions observed. It is a place where we search for techniques to address what ails us as a society or to reclaim something of what we have lost. It is a place where the distracted attention characteristic of modernity, and perhaps even more so in our accelerated modernity (or supermodernity), ${ }^{22}$ can be enacted and ameliorated; a single yet multi-faceted place where we can be confounded by shifting vistas and complex contradictions yet also comforted and challenged by the ways that culture can be reanimated and revived through public art. 


\section{MONTAGE}

Montage in film is typically achieved in editing by juxtaposing different shots with one another, cutting and recombining film in order to create relationships between images from different times and/or places. The practice of montage has expanded over time to include the additional use of the composite image within frames (itself a form of superimposition) that has accelerated greatly with digital editing techniques. Lev Manovich refers to this as "spatial montage," ${ }^{23}$ describing such as a unique characteristic of new media. Still, through cutting and recombining film or altering layers within the digital frame, this kind of montage remains purely diegetic and does not address spatiality in terms of the space around the presentation of the film itself it. Rarely if ever does montage, in the traditional or digital sense, explicitly reference or interact with the frame, be it the plush curtains of a darkened theater, a television set or more commonly now a mobile device, and that which lies beyond. The nature of montage changes when the moving image departs from standardizing formats of the cinema, television screen or mobile device, abandoning their present day interoperability and remediation (the any place, any time, any where-ness of contemporary media) for a singular specificity precisely located on a unique architectural surface within the larger frame of a gallery or, in what I will focus on here, the urban environment. ${ }^{24}$ Similar to early installation works that incorporated the moving image into the gallery space, montage in urban space engenders greater narrative and associative flexibility between moving images and architecture. 
In his theorization of expanded cinema, a movement identified in the 1970s that considers uses of the cinema outside of the theater and specifically in art and installation, Gene Youngblood pointed to the growing need of moving image practitioners to pay attention to what was beyond the picture plane and thus to include it within a multisensory experience that can potentially liberate new degrees of creative freedom. ${ }^{25}$ Even before the sometimes reactive or interactive experiments of expanded cinema and media artists of the 1960s and 70s (such as Carolee Schneemann's 1967 audience activated performance and film installation Snows, and Nam June Paik's microphone modulated Participation TV of 1963), creative juxtapositions of materiality, space and the moving image were present in the display of public culture. The multi-screen experiments and proto-expanded cinema of Charles and Ray Eames explored ways to make the moving image integral to architectural and spatial experience. With Glimpses Of The USA (1959), the Eameses created a multi-screen expanse within the United States pavilion at the 1959 American National Exhibition in Moscow. ${ }^{26}$ Situated within a Buckminster Fuller designed geodesic dome, and presenting images of highways, bridges, homes and subdivisions in multiples across seven screens that spanned approximately four football fields (accompanied by narration and music), the Eameses created a visual field which gained much of its impact from its immensity and the interrelationship of multiple images within a space built for a specific purpose. In form and content it reinforced claims of mastery over nature, good design and culture. The message of Glimpses was that the U.S. was a vast country of abundance and technical 
sophistication and its method of delivery, a multi-screen spatial montage, was part of this. In the case of the Eameses work, as well as the Wodiczko projections mentioned above, the elements outside of the picture planehistorically and semiotically relevant architectural and civic infrastructure, spectators and location—became important elements of an expanded diegesis and potent ingredients in the ongoing experiments in merging architecture and the moving image. Unlike Crary's and Simmel's proclamations of distraction and mystification, Youngblood and the Eameses suggest a potential for expository power and creative freedom through the fragmented recombination of still and moving images in relation to space and architecture.

Youngblood and the Eameses saw a perceptual laboratory emerging from spatialized cinema that can enable the viewer to perceive and experience space and the moving image in potentially democratic and liberating ways. The work of Bauhaus pioneer Herbert Bayer, whose exhibition design for Edward Steichen's Family of Man at the Museum of Modern Art (MoMA) in 1955 employed multiple panels, sizes and angles of text and imagery, further manifested this thinking about media and space. Bayer hoped to develop an "extended field of vision technique" that would prompt viewers to adjust their consumption of images and space ${ }^{27}$ providing a so-called "democratic" means for them to recombine and digest information. ${ }^{28}$ These new forms of distraction became a means for developing other types of awareness, first through disruption and then, hopefully, through habituation and mastery. Bayer's work on the Family of Man exhibition represents one point in the development of spatial montage in the presentation of 
moving images enabling viewers to take in more information and create associative meanings of their own across spatial arrangements, be it in the gallery or in urban space, essentially creating a unique viewer centered experience from an expanded apparatus of exhibition.

The relationships between image, spectator and environment become material for spatial montage by artists who create site specific, large-scale public screen and projection experiences. In this sense montage juxtaposes the moving image with its surroundings, creating new and rich possibilities for semiotic relationships and enacts the productive tensions between distraction/attention and disruption/habituation in the peripatetic viewer of the moving image in public space. $^{29}$

The Image Mill (2008-13) by Ex Machina and Robert Lepage (a massive outdoor public projection that celebrated the $400^{\text {th }}$ anniversary of Quebec City by mixing archival footage, motion graphics, light and sound on a 300 meter-wide wall of grain silos in the lower town of the city) exemplifies the concept of spatial montage, both with respect to its setting but also to the scale of its presentation. When placed within a context where scale can be measured directly in relation to the real world elements from which it is drawn, cinematic effects in public projection such as spatial montage enable cinema to drive perceptual experimentation in public space in a particularly potent way when superimposed onto a setting such as that of The Image Mill. The diegetic montage of The Image Mill cycled through different scales accentuated and complimented by the space around it. From magnified microscopic science experiments (demonstrating the 
development of chemical industries in the city) that seemed larger than life, to the cosmos (illustrating the ways early explorers navigated across the sea) blending in with the night skies above, to images of historical structures shown to scale (to tell the stories of religion and commerce) so that they might be felt against the human form, the diegesis explored the contrasts and comparisons enabled by the work's real world setting (Figure 3).

The Image Mill also conveys a form of "creative geography" through the framelessness of spatial montage. In his analysis of film Kracauer discusses "creative geography,"30 originally a theory posited by Kuleshov, in which spatial interrelationships are created and dissolved when material phenomena from different places are juxtaposed in the diegesis. With The Image Mill's spatial montage, relationships between the material phenomena of the city and that depicted in moving images were created and dissolved, as evidenced in a scene where ships appeared to enter into the harbor to signify the arrival of Samuel de Champlain's fleet to Quebec City in 1608. As illustrations of the ships entered the scene on the 300 meter-wide expanse, the creaking of ships and the sounds of seagulls could be heard through loudspeakers at the site. Whether experienced from the docks across from the silos or further up the hills of the city (on a radio frequency provided for the show), a new form of creative geography—a spatial montage-was engaged between the immediate sights and sounds of actual ships and birds in the harbor, the city and the historical re-enactment behind it. The frame that The Image Mill acknowledged in its diegesis was not the edge of the projection so much as it was the entire city, a city that was made to resonate 
with the narrative and associative content presented with it. Other more specific effects such as the subwoofers that were installed under the docks adjacent the projection, as well as key scenes in which smoke was triggered to billow out of the top of the silos matched to factory scenes projected onto the building, emphasized the framelessness of the experience and created more spatial and perceptual correlations. Together these effects represented an ontological blurring between diegesis and surroundings, between figure and ground. Thus spatial montage contributes to the framelessness of the experience of the moving image in public space, extending not only our field of vision but also expanding the field of representation and the possibilities for site specificity, narrative and association with public art.

Building upon these observations I have further explored the creative possibilities of spatial montage in a number of my works. ${ }^{31}$ One such project, created with collaborator Patricio Davila, is Workers That Live In The Mirror (2013), a 60 -foot by 20 -foot projection that featured a variety of contemporary and historical moving image sources depicting workers leaving, entering or blocking factories, projected onto an abandoned factory-turned-art-gallery in downtown Toronto. Workers aimed to utilize the special effects of superimposition and montage in a historically charged urban space. It also sought to address consumerism, gentrification, popular culture and the nature of contemporary moving image production by presenting clips depicting work and resistance (and its representation in film and more contemporary channels for the moving image such as YouTube) by situating these images in a spatial montage 
with a former factory building and the crowds of people entering and leaving it. The moving images presented included early films by the Lumière brothers and Fritz Lang as well as YouTube footage of workers' resistance movements in Argentina and factory workers leaving the Foxconn factory in China (where consumer electronics such as the iPhone are manufactured). The images were split and mirrored along a center line that corresponded to the space above the main doors of the former factory. In presenting this work on the façade of the building the architectural features as well as the crowds entering and exiting the gallery (as they would have when the factory existed) reinforced the symbolic and visceral effects of the video, which prompted spectators to reflect on their positions within this interplay of history, image and space. Spatial montage, along with superimposition, did the work of creatively rehistoricizing the building amidst its rapidly gentrifying surroundings, embodying the consequences of previous economic and symbolic modes of representation and the promise and pitfalls of new ones (Figure 4). Spatial montage in public art merges the immaterial moving image with the material images behind and around it to create new semiotic potentialities that artists can use to recode and rehistoricize space.

\section{APPARATUS/DISPOSITIF}

In The Cinema Spectator Raymond Bellour notes that cinema is a simple hypothesis with many detours. ${ }^{32}$ The darkened theater with a hidden source of projection is just a standardized technicity from which "every other viewing situation more or less departs." ${ }^{33}$ In art that employs the moving image, the 
installation remains one of the most varied and productive sites for said detours. That said we might ask: how does public art that employs the moving image follow from the standard technicity of the cinema, but also how does it depart from such? And to which effect?

"Dispositif" and "apparatus" are two terms that have been used to describe cinematic situations. Definitions of these terms will aid in the analysis that follows. Fraçois Albera and Maria Tortjada define dispositif as designating "any type of technical organisation or construction, or any arrangement, including with human actors, as long as it correlates actantial positions and relations." ${ }^{\text {34 }}$ This definition draws upon Foucault's definition of the term (often confusingly and imprecisely translated as apparatus). Foucault defines dispositif as: "a thoroughly heterogeneous ensemble consisting of discourses, institutions, architectural forms, regulatory decisions, laws, administrative measures, scientific statements, philosophical, moral and philanthropic propositions-in short, the said as much as the unsaid." ${ }^{35}$ Thus dispositif conveys the power embedded in socio-spatial ensembles that place actors (living and inanimate) into specific relationships and directs them to experience themselves and the space they are in in prescribed ways. Apparatus, in contrast to dispositif will (again for the purposes of this analysis) refer to a subset of dispositif: the technical aspects of this relational field of actors. Albera and Tortjada describe the dispositif of cinema as "a network of relations between a spectator, the representation and the 'machinery' that allows the spectator to have access to the representation.. ${ }^{36}$ Here the "machinery" is the apparatus and would include the camera, projector, architecture of the theater 
and so on. With cinema we can say dispositif is the ideological interface that captures and captivates, delivering and recentering an audience to a set of discourses via technical means (apparatus). Together, apparatus and dispositif constitute a special effect of cinema that captures audiences and delivers messages to them through a combination of concept, content and form.

I would argue that one characteristic of the cinematic dispositif made possible by projection that is amplified in public art is the role scale plays in determining relations of power and attention in scenarios of spectatorship. Mary Anne Doane analyzes the way that cinematic scale reflects a desire to lose oneself in the image—an essential quality for ideological transmission through any media form achieved, to a degree, by the dispositif or relationship created between the content, environment and spectator. ${ }^{37}$ She sees scale as part of a historical progression in media that has tended toward the destabilization of scale as proportionate and representational: a tendency toward the immersive. Doane argues that expanded cinema (and I would add large-scale architectural projections and other moving images in public space) resuscitates the body as a measure of scale and distance in physical space that has been lost to a degree in the practice of more traditional cinematic spectatorship. The expanded proscenium of public projection demands that the screen be considered in relation to the body and its surroundings and that spectators actively negotiate with other potentially non-cooperative or indifferent entities that place them at the center of a field of an intensely personal relationality. This differs from the effect of cinema or the black box approach typical of the gallery setting where the 
spectator's proprioception is diminished, delivering them to some aspect of the diegesis, whether that be an identification with a subject in a film or with the camera itself. With large-scale outdoor projections such as The Image Mill spectators are delivered to the diegesis, but the diegesis in this case includes the entire spatial environment of the city all around them. The experience then is less immersive than it is total, that is, the experience necessarily includes a consideration of what the building is, where it is, where images are located, and is modulated precisely by the physical presence, identity and location of the viewer.

In addition to the evolving use of scale in public moving images, direct participation and interaction also serve as recentering devices. Interactive elements afforded by tangible interfaces at the site or ubiquitous mobile media represent aspects of the expanded dispositif of cinema that help to capture and deliver audiences to new experiences of history and memory through public art and extend the possibilities for aesthetic and political experimentation in public space. Perhaps the most consistent site for this kind of experimentation in the last decade has been the Quartier des Sspectacles in Montreal. Since 2003 the Quartier des Sspectacles (a coordinated area of public squares, stages, lighting and permanent architectural projection sites) has been at the forefront of developing interactive moving image art experiences in public space. One recent example by the interactive design studio Daily tous les jours, McLarena (2014), demonstrated novel ways that the city, the moving image and architecture can be combined with interactive techniques of capture that place the body in direct 
relation with historical material and other spectators in public space (Figure 5). McLarena asked participants to watch and mimic Norman McLaren's original film Canon (1964) while their images were captured, automatically processed and presented on the architectural façade situated next to the Saint-Laurent metro station. Along with a durable recording unit built from a shipping container, the installation included a tiered seating space so that people could watch the performances of the participants and their projection almost simultaneously.

While building upon traditional means for capturing attention and generating affect and meaning in the cinema (superimposition, montage and apparatus/dispositif), McLarena augmented the apparatus/dispositif of the moving image by including a powerful suturing device of direct involvement through interactivity. McLaren's film was simultaneously viewed by participants in the mobile recording unit, learned and remediated through their bodies, and then processed, amplified and represented in the style of McLaren's film. Each of these elements served to deliver the various "actants" (viewers, participants and passersby) to the installation through an expanded apparatus that included direct participation. At the same time McLarena presented an interesting mix of older cinematic techniques repurposed for a monumental projection installation: the literal superimposition of the participant in the diegesis, the superimposition of the larger image within the cityscape, the spatial montage that put that installation in relationship to the surrounding architecture and flows of pedestrians and cars, the traditional viewing conditions of seating augmented by an expanded scale, and the addition of a space for interaction that sutured the interactants to the 
image. Thus McLarena also created new narrative and associative dimensions for the archival moving images presented through a mediated encounter that mixed new technical practices and public space.

\section{CONCLUSION}

The increased prevalence of urban screens and interactive and/or mapped public projections (such as Wodizcko's War Veteran Projection or Daily tous les jours' McLarena) demonstrate two things about the history and future of public art and the moving image: 1) moving image based installations in public space may be seen as an extension of cinema's foundational techniques and can be analyzed to uncover how superimposition, montage and apparatus/dispositif have evolved with and in public spaces; and 2) the moving image in public space extends the function of the cinema as a perceptual laboratory that both challenges and enhances historical awareness and personal and collective identity. These scenarios can serve to dehistoricize and mystify, as they did in the case of Freud's experience of projections in the Piazza Colonna in Rome, but they can also rehistoricize a space—be it a historical statue or a wide expanse of industrial concrete-and reinvigorate it and the respective public through the considered superimposition of the moving image. This prompts a dialogue with peripatetic audiences and the expanded diegesis of the cityscape. As our surroundings become hybridized through technologies such as augmented reality and ever more ubiquitous digital screens, we will have been both shocked by and trained 
to live with them by the expanded cinema of public projection and screen based installations.

The history of cinema and media studies appears to provide helpful correlatives and analytical tools for understanding increasingly mediatized public spaces and public art. One area in which this analysis might be extended is to take a closer look at the specific differences between the use of live and prerecorded images in large-scale public artworks, as well as the testing of new forms of public sociability through live images exchanged between public screen scenarios in different cities. Due to the rapid pace of change in this field, creationas-research may also be a useful method for analyzing these shifting circumstances of public space and the moving image. A socially engaged practice of public art that employs the moving image-particularly the digital, mapped and interactive one-may, for example, be used to refine techniques and test hypotheses for the development of a public sphere that is challenging, engaging and just.

\section{CAPTIONS}

Figure 1. Krzysztof Wodiczko. Tijuana Projection. 2001. Public projection of live images and sound at the Centro Cultural de Tijuana, Tijuana, Mexico, as part of InSite 2000. @ Krzysztof Wodiczko, Courtesy Galerie Lelong, New York. 
Figure 2. Krzysztof Wodiczko, Abraham Lincoln: War Veteran Projection. 2012. Public projection of images and sound at Union Square Park, New York City. () Krzysztof Wodiczko, Courtesy Galerie Lelong, New York.

Figure 3. Robert Lepage and Ex Machina. Le Moulin à images/The Image Mill. 2008-2013. Public projection of images and sound in Quebec City. Photography: Nicola-Frank Vachon @ 2012.

Figure 4. Dave Colangelo and Patricio Davila. Workers That Live In The Mirror. 2013. Public projection of images at Tower Automotive Building, Toronto.

Photograph: Ian M. Campbell @ 2013.

Figure 5. Daily tous les jours. McLarena. 2014. Public projection of live images and sound at Quartier des Spectacles, Montreal. Photography: Martine Doyon ( 2014.

\section{NOTES}

${ }^{1}$ Laura Mulvey, "Visual pleasure and narrative cinema," in Film Theory and Criticism: Introductory Readings, eds. Leo Braudy and Marshall Cohen (New York City, NY: Oxford University Press, 1999), 837.

${ }^{2}$ Scott McQuire, The Media City: Media, Architecture, and Urban Space (London: Sage, 2008), 114.

${ }^{3}$ Susan Buck-Morss, "Dream World of Mass Culture: Walter Benjamin's Theory of Modernity and The Dialectics of Seeing," in Modernity and the Hegemony of Vision, ed. David Michael Kleinberg-Levin (Berkeley, CA: University of California Press, 1993).

${ }^{4}$ McQuire. 
${ }^{5}$ Lev Manovich, The Language of New Media (Cambridge, MA: The MIT Press, 2001).

${ }^{6}$ Gene Youngblood, Expanded Cinema (New York City, NY: Dutton, 1970), 87.

${ }^{7}$ Janet Harbord, The Evolution of Film: Rethinking Film Studies (Cambridge, UK: Polity, 2007).

${ }^{8}$ Marshall Berman, "Too Much is Not Enough: Metamorphoses of Times Square," in Impossible Presence: Surface and Screen in the Photogenic Era, ed. Terry Smith (Chicago, IL: University of Chicago Press, 2001).

${ }^{9}$ Jonathan Crary, Suspensions of Perception: Attention, Spectacle and Modern Culture (Cambridge, MA: MIT Press, 1999), 468.

${ }^{10}$ Crary 367.

${ }^{11}$ Crary 363.

12 Crary 366.

${ }^{13}$ Crary 369.

${ }^{14}$ Berman 42.

${ }^{15}$ Georg Simmel, "The Metropolis and Mental Life," in The Sociology of Georg Simmel, trans. by Kurt Wolff (New York City, NY: Free Press, 1950).

${ }^{16}$ Harbord.

${ }^{17}$ D.N. Rodowick, The Virtual Life of Film (Cambridge, MA: Harvard UP, 2007).

${ }^{18}$ Siegfried Kracauer, Theory of Film; The Redemption of Physical Reality (London, UK: Oxford University Press, 1960), 158.

${ }^{19}$ Krzysztof Wodiczko, "The Inner Public," FIELD 1 (Spring 2015). http://fieldjournal.com/issue-1/wodiczko (accessed 1 Jun. 2015).

${ }^{20}$ Kevin Lynch, The Image of The City (Cambridge, MA: The MIT Press, 1960), 119.

${ }^{21}$ McQuire 114.

${ }^{22}$ Marc Augé, Non-Places: Introduction to an Anthropology of Supermodernity (London, UK: Verso, 1992/1995).

${ }^{23}$ Manovich 323.

${ }^{24}$ André Gaudreault and Philippe Marion, La Fin du Cinéma? (Paris, France: Armand Colin, 2013). 
${ }^{25}$ Youngblood.

${ }^{26}$ Beatriz Colomina, "Enclosed by Images: The Eameses' Multiscreen Architecture," in Art of Projection, eds. Stan Douglas and Christopher Eamon, (Stuttgart, Germany: Harje Cantz, 2009).

${ }^{27}$ Fred Turner, "The Family of Man and the Politics of Attention in Cold War America," Public Culture 24.1: 83.

${ }^{28}$ Fred Turner, The Democratic Surround: Multimedia \& America Liberalism from World War II to the Psychedelic Sixties (Chicago, IL: The University of Chicago Press, 2013), 9.

${ }^{29}$ Susan Bennett, "The Peripatetic Audience," Canadian Theatre Review 4 (Fall 2009).

${ }^{30}$ Kracauer 48.

${ }^{31}$ Dave Colangelo, "Dave Colangelo." http://davecolangelo.com/ (accessed 1 Jun. 2015).

${ }^{32}$ Raymond Bellour 206.

${ }^{33}$ Bellour, "The Cinema Spectator: A Special Memory," in Audiences, ed. Ian Christie (Amsterdam, Netherlands: Amsterdam University Press, 2012), 206.

${ }^{34}$ François Albera and Maria Tortjada, "Introduction to an Epistemology of Viewing and Listening Dispositives," in Cinema Beyond Film: Media Epistemology in the Modern Era, eds. François Albera and Maria Tortjada (Amsterdam, Netherlands: Amsterdam University Press, 2010), 10.

${ }^{35}$ Michel Foucault, Power/Knowledge: Selected Interviews and Other Writings 1972-1977, ed. Colin Gordon (New York City, NY: Pantheon, 1980), 194.

${ }^{36}$ Albera and Tortjada 12.

${ }^{37}$ Mary Ann Doane, "The Location of the Image: Cinematic Projection and Scale in Modernity," in The Art of Projection, eds. Stan Douglas and Christopher Eamon (Stuttgart, Germany: Hatje Cantz, 2009). 


\section{BIBLIOGRAPHY}

Albera, François, and Maria Tortjada. "Introduction to an Epistemology of Viewing and Listening Dispositives." In Cinema Beyond Film: Media Epistemology in the Modern Era. Eds. François Albera and Maria Tortjada. Amsterdam, Netherlands: Amsterdam University Press, 2010.

Augé, Marc. Non-Places: Introduction to an Anthropology of Supermodernity. London, UK: Verso, 1992/1995.

Bennett, Susan. "The Peripatetic Audience." Canadian Theatre Review 4 (Fall 2009): 8-13.

Berman, Marshall. "Too Much is Not Enough: Metamorphoses of Times Square." In Impossible Presence: Surface and Screen in the Photogenic Era. Ed. Terry Smith. Chicago, IL: University of Chicago Press, 2001. 39-69.

Buck-Morss, Susan. "Dream World of Mass Culture: Walter Benjamin's Theory of Modernity and The Dialectics of Seeing." In Modernity and the Hegemony of Vision. Ed. David Michael Kleinberg-Levin. Berkeley, CA: University of California Press, 1993. 309-38.

Bellour, Raymond. "The Cinema Spectator: A Special Memory." In Audiences. Ed. Ian Christie. Amsterdam, Netherlands: Amsterdam University Press, 2012. 206-217.

Colomina, Beatriz. "Enclosed by Images: The Eameses' Multiscreen Architecture." In Art of Projection. Eds. Stan Douglas and Christopher Eamon. Stuttgart, Germany: Harje Cantz, 2009.

Crary, Jonathan. Suspensions of Perception: Attention, Spectacle and Modern Culture. Cambridge, MA: MIT Press, 1999.

Doane, Mary Ann. "The Location of the Image: Cinematic Projection and Scale in Modernity." In The Art of Projection. Eds. Stan Douglas and Christopher Eamon. Stuttgart, Germany: Hatje Cantz, 2009.

Foucault, Michel. Power/Knowledge: Selected Interviews and Other Writings 1972-1977. Ed. Colin Gordon. New York City, NY: Pantheon, 1980.

Gaudreault, André, and Philippe Marion. La Fin du Cinéma? Paris, France: Armand Colin, 2013.

Harbord, Janet. The Evolution of Film: Rethinking Film Studies. Cambridge, UK: Polity, 2007. 
Kracauer, Siegfried. Theory of Film; The Redemption of Physical Reality. London, UK: Oxford University Press, 1960.

Lynch, Kevin. The Image of The City. Cambridge, MA: The MIT Press, 1960.

Manovich, Lev. The Language of New Media. Cambridge, MA: The MIT Press, 2001.

McQuire, Scott. The Media City: Media, Architecture, and Urban Space. London, UK: Sage, 2008.

Mulvey, Laura. "Visual pleasure and narrative cinema." In Film Theory and Criticism: Introductory Readings. Eds. Leo Braudy and Marshall Cohen. New York City, NY: Oxford University Press, 1999. 833-44.

Rodowick, D.N.. The Virtual Life of Film. Cambridge, MA: Harvard UP, 2007.

Simmel, Georg. "The Metropolis and Mental Life." In The Sociology of Georg Simmel. Trans. by Kurt Wolff. New York City, NY: Free Press, 1950. 40924.

Turner, Fred. The Democratic Surround: Multimedia \& America Liberalism from World War II to the Psychedelic Sixties. Chicago, IL: The University of Chicago Press, 2013.

Turner, Fred. "The Family of Man and the Politics of Attention in Cold War America." Public Culture 24.1: 55-84.

Wodiczko, Krzysztof. "The Inner Public." FIELD 1 (Spring 2015). http://fieldjournal.com/issue-1/wodiczko (accessed 1 Jun. 2015).

Youngblood, Gene. Expanded Cinema. New York City, NY: Dutton, 1970. 